\title{
Effects of Housing Systems on Biochemical Indicators of Blood Plasma in Laying Hens
}

\author{
A. PAVLÍK ${ }^{1}$, M. POKLUDOVÁ ${ }^{2}$, D. ZAPLETAL ${ }^{3}$, P. JELÍNEK $^{1}$ \\ ${ }^{1}$ Department of Animal Morphology, Physiology and Genetics, ${ }^{2}$ Department of Animal Breeding, Mendel \\ University of Agriculture and Forestry, Brno, Czech Republic \\ ${ }^{3}$ Department of Nutrition, Animal Husbandry and Animal Hygiene, Faculty of Veterinary Hygiene and Ecology, \\ University of Veterinary and Pharmaceutical Sciences, Brno, Czech Republic \\ Received January 29, 2007 \\ Accepted July 9, 2007
}

\begin{abstract}
Pavlík A., M. Pokludová, D. Zapletal, P. Jelínek: Effects of Housing Systems on Biochemical Indicators of Blood Plasma in Laying Hens. Acta Vet. Brno 2007, 76: 339-347.

The aim of this study was to compare biochemical indicators of blood plasma of laying hens housed in three different housing systems (conventional cage system, enriched cage system and deep litter system). In each housing system, 12 ISA Brown laying hens were observed during the laying period from week 22 to 75 of age. Blood samples for determination of biochemical indicators in plasma were collected during this period in week 22, 47 and 75. Indicators of blood plasma metabolic profile of laying hens of all monitored groups during the laying period ranged in intervals stated for healthy animals. In some cases, significant differences between housing systems were found, however, these differences do not give clear evidence of the influence of the housing system on the health of animals. The differences were apparently due to different efficiency of each group during the laying period.
\end{abstract}

Housing system, blood, total protein, glucose, cholesterol, uric acid, alkaline phosphatase

Public concerns about the welfare of laying hens resulted in minimum welfare directives in the European Union, with the imposing of a ban on conventional cages in 2012 (European Commission, 74/1999). Since then, cages are allowed only if enriched with nests, perches, and dust baths, i.e. facilities that improve the behavioural repertoire of the birds (Wall and Tauson 2002). Group size has been shown to have a significant effect on production traits. The general trend in layer strains is higher mortality, more feather and skin damage, and lower egg production as group size increases (Tauson 1998; Bilčík and Keeling 1999). The conventional cage was the most common housing system in Europe because of the advantages of more disease-free birds, allowing e.g. the prevention of coccidiosis (Appleby and Hughes 1991), and less bird aggression and cannibalism (Abrahamsson and Tauson 1995). Smaller group sizes consisting of 6 hens or less are associated with easier bird inspection and cleaner eggs (Bell and Adams 1998), and are economical (van Horne et al. 1998; Appleby et al. 2002) compared with alternative housing systems such as deep litter technology. Enriched and modified cages for small groups of hens seem more realistic as alternative systems in large-scale production than deep litter systems, in which birds are kept in larger groups (Tauson 1998). De Boer and Cornelissen (2002) consider the battery cage system, particularly from the perspective of production and several health indicators, to be more beneficial than the aviary systems.

Determination of the indicators of internal environment is one of the methods of evaluating the effect of the factors of housing environment on health and production of farm animals. It provides valuable information about relations between the internal environment of the organism, nutrition, age and performance. It contributes to an objective 
evaluation of functional and health condition and helps to discover and to diagnose animal diseases (Kredatus and Valent 1993). The changes in the content of total protein correlate closely with the metabolic changes in the animal organism, and reflect various disorders of nutritional character, the cause of which is either insufficient or excessive intake of proteins in feed mixtures. The level of blood plasma glucose is maintained at a relatively stable level with highly sensitively controlled homeostatic mechanisms. The level of glycaemia changes in the course of growth and maturation, depending on the intake of feed, production performance as well as in relation to the change of the environment (Nasreldin et al. 1988). Cholesterol has a proven relationship with the metabolism of bile acids, sexual hormones and other steroid substances (Griffin 1992). The effect of the age of laying hens also contributes during changes of cholesterol concentration (Suchý et al. 1995, 1999). Uric acid level fluctuates depending on the intake of purines and its increased amount in blood often accompanies the symptoms of gout. Its concentration increases with elevated temperature in the environment (Koelkebeck and Odom 1995). Determination of the alkaline phosphatase (ALP) activity is one of the most important clinical and biochemical examinations during the monitoring of the metabolic profile of the hens' blood.

\section{Materials and Methods}

Animals and breeding conditions

The experiments were performed on ISA BROWN pullets, kept in a hall with deep litter. The available area, complete feeding mixture, light-dark (L : D) cycle, housing temperature, relative air humidity changed according to technological instructions for ISA BROWN pullets. During the rearing period standard vaccinations were provided. At the age of 15 weeks, they were randomly divided into 3 of the following housing systems:

- conventional cage housing system - four-floor, total (available) area $550 \mathrm{~cm}^{2} / \mathrm{bird}$ (2 birds kept on $1120 \mathrm{~cm}^{2}$ $32 \times 35 \times 45 \mathrm{~cm}), 2$ nipple drinkers, belt feeder $15 \mathrm{~cm} /$ bird, device for claw shortening,

- enriched cage housing system according to Council Directive 99/74/EC - three-floor, total area $945 \mathrm{~cm}^{2} / \mathrm{bird}$ ( 8 birds kept on an area of $7560 \mathrm{~cm}^{2}-180 \times 42 \times 45 \mathrm{~cm}$ ), available area $643 \mathrm{~cm}^{2} /$ bird, 6 nipple drinkers, belt feeder $20 \mathrm{~cm} /$ bird, nest $(30 \times 35 \times 45 \mathrm{~cm})$, perching area $15 \mathrm{~cm} /$ bird, devices for dust bathing and scratching, device for claw shortening,

- deep litter housing system - available area $2000 \mathrm{~cm}^{2} /$ bird (20 birds kept on an area of $40000 \mathrm{~cm}^{2}-200 \times 200$ $\times 180 \mathrm{~cm}$ ), tube feeder $5 \mathrm{~cm} /$ bird, round drinker $2 \mathrm{~cm} /$ bird, deep litter made from wood shavings.

All of the housing systems were situated in the same building with central system of ventilation and temperature regulation. For each system, experimental group consisting of 12 birds was established with the mean body weight of $1300 \pm 50 \mathrm{~g}$. Throughout the study, the hens were fed using a complete feeding mixture for laying hens containing $875 \mathrm{~g} \cdot \mathrm{kg}^{-1}$ of dry matter, energy content $\mathrm{ME}_{\mathrm{N}} 11.1 \mathrm{MJ} \cdot \mathrm{kg}^{-1}$, content of crude protein $170.7 \mathrm{~g} \cdot \mathrm{kg}^{-1}$, Ca $35.9 \mathrm{~g} \cdot \mathrm{kg}^{-1}$ and P $6.3 \mathrm{~g} \cdot \mathrm{kg}^{-1}$. A constant light-dark (L : D) cycle (15:9, switching on at $4.00 \mathrm{~h}$, switching off at $19.00 \mathrm{~h}$ ) was maintained in all three systems as recommended in technological instructions for ISA BROWN hens. The temperature of housing was in the range of 18 to $22^{\circ} \mathrm{C}$; relative air humidity ranged from 65 to $70 \%$. No red mite or other parasite or viral infection was presented during experimental period.

Collection of blood samples

Blood samples $(3 \mathrm{ml})$ of all hens in experimental groups were collected from a brachial vein of hens at the age of 22, 47 and 75 weeks, always between 7.00 and $8.30 \mathrm{~h}$. EDTA was used as anticoagulant. Blood samples were centrifuged and the separated plasma was stored at $-20^{\circ} \mathrm{C}$ until analyzed. Blood sampling was performed randomly in hens kept in conventional, enriched and deep litter system.

Egg production and body weight

Next to the determination of plasma metabolite levels, the body mass of the animals and the egg production were evaluated. The egg production was recorded weekly during the laying period and it was expressed in percentage as laying intensity. The individual body weight of laying hens was determined at the beginning of the laying period and in weeks 22,47 and 75 .

Measurement of biochemical indicators

Blood plasma was also subjected to the following biochemical tests: total protein, glucose, cholesterol, uric acid and alkaline phosphatase. Analyses were provided photometrically with commercially available kits Bio-LaTests made by Pliva-Lachema, a.s., Czech Republic, on COBAS MIRA S analyzer (Roche).

Statistical evaluation

The data are expressed as means \pm SEM. Changes in egg production were analyzed by One-way ANOVA for factor housing system. Changes in biochemical indicators and body weight were analyzed by repeated measures 
ANOVA for factors housing system as independent variable and age of hens as dependent variable. ANOVA was followed by post-hoc Fischer LSD test for pair-wise comparisons, when appropriate. All statistical analyses were performed by Statistica 7.0 statistical software (StatSoft Inc., Tulsa, USA). The overall level of statistical significance was defined as $p<0.05$.

\section{Results}

Housing system significantly influenced the intensity of egg production (Fig. 1). Oneway ANOVA revealed the main effect for factor housing system $(\mathrm{F}(2,102)=53.470, p<$ $0.001)$. Fischer post hoc test showed a significantly lower intensity of egg production in hens exposed to deep litter housing system than those exposed to conventional conditions or enriched environment.

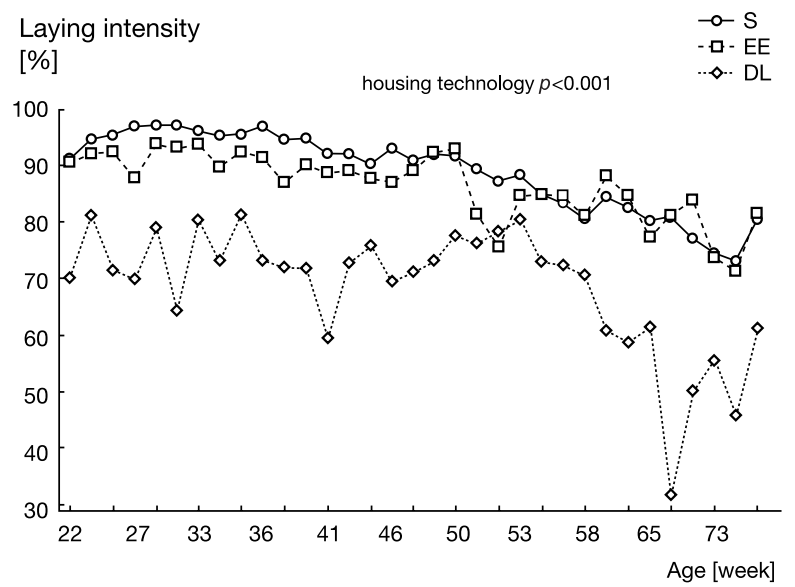

Fig. 1. Laying intensity of hens kept in conventional $(S, n=12)$, enriched $(E E, n=12)$ and deep litter (DL, $\mathrm{n}=12$ ) housing system during laying period. Data represent mean values.

The body weight (Fig. 2) of hens increased significantly in all experimental groups during the whole experiment. Two-way ANOVA with repeated measures for factor time revealed the main effect for factor housing system $(\mathrm{F}(2,29)=4.1443, p<0.05)$. There were significant differences in factor time $(\mathrm{F}(3,87)=314.82, p<0.001)$ as well as system and time interaction $(\mathrm{F}(3,87)=314.82, p<0.001)$. Fischer post hoc test showed a significantly higher body weight gain in hens housed under conventional conditions than in those exposed to deep litter system in the week 22. At the end of the experiment (week 75 ), hens housed under conventional conditions had significantly greater bodyweight than hens kept in enriched environment.

Concentration of total proteins during the laying period in all animals did not significantly change (Fig 3), which is proved by the results of two-way ANOVA with repeated measures for factor time $(\mathrm{F}(2,66)=0.406, p=0.667)$. No significant difference in the concentration of total protein was determined between individual groups $(\mathrm{F}(2,33)=0.708, p=0.499)$.

The housing system had no effect on the concentration of glucose in blood plasma (Fig. 4 ), as shown in two-way ANOVA with repeated measures for factor housing system ( $\mathrm{F}$ $(2,33)=0.2154, p=0.8073)$ as well as system and time interaction $(\mathrm{F}(4,66)=0.410, p$ $=0.801)$. However, during the laying period, there was a significant change in glucose concentration $(\mathrm{F}(2,66)=19.161, p<0.001)$. The Fischer post hoc test showed a significant $(p<0.01)$ increase in week 47 and a subsequent decrease in glucose concentration in week 75 in all housing systems. 


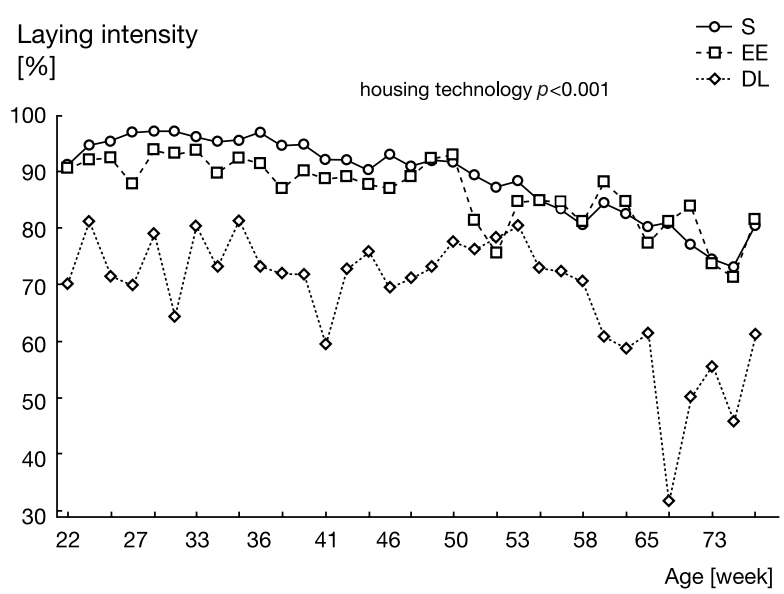

Fig. 2. Body weight of laying hens kept in conventional $(S, n=12)$, enriched $(E E, n=12)$ and deep litter $(D L, n=$ 12) housing system during experimental period. Data represent mean \pm S.E.M. ** represent statistical significance $p<0.01, *$ represent statistical significance $p<0.05$.

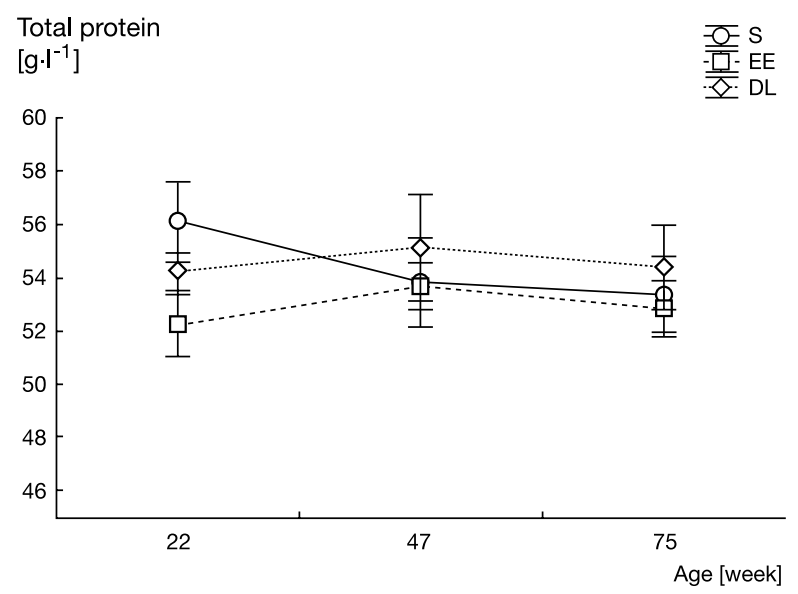

Fig. 3. Plasma total protein concentration in laying hens kept in conventional $(\mathrm{S}, \mathrm{n}=12)$, enriched $(\mathrm{EE}, \mathrm{n}=12)$ and deep litter $(\mathrm{DL}, \mathrm{n}=12)$ housing system during experimental period. Data represent mean \pm S.E.M.

The highest concentration of cholesterol was recorded during the experimental period in conventional cage technology, although this difference was not statistically significant $(\mathrm{F}(2,33)=0.731, p=0.488)$ compared with other systems. Concentration of cholesterol in blood plasma of laying hens increased in all groups from week 22 to 75 of age (Fig. 5) and this increase was determined as statistically significant $(\mathrm{F}(2,66)=34.341$, $p<0.001)$. The Fisher post hoc testing showed a significant increase of the cholesterol level in the conventional, enriched and deep litter housing system in week $47(p<0.01)$ and the enriched system in week $75(p<0.05)$.

The concentration of uric acid in blood plasma decreased in each system from the beginning of the experiment to week 47 with a following increase in week 75 (Fig. 6). These changes were not determined as significant for factor time $(\mathrm{P}(2,66)=2.707$, $p=0.074)$. The average concentrations of uric acid in the deep litter system were significantly 


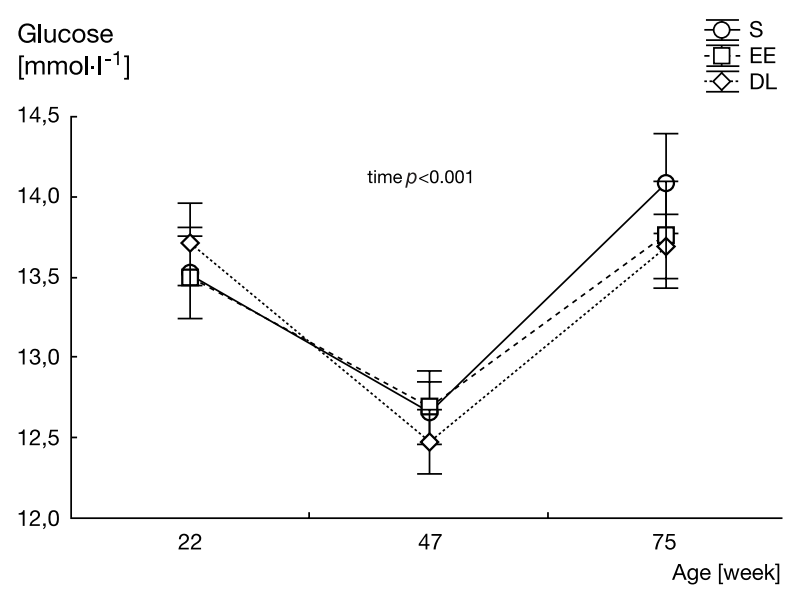

Fig. 4. Plasma glucose concentration in laying hens kept in conventional $(S, n=12)$, enriched $(E E, n=12)$ and deep litter $(\mathrm{DL}, \mathrm{n}=12$ ) housing system during experimental period. Data represent mean \pm S.E.M.

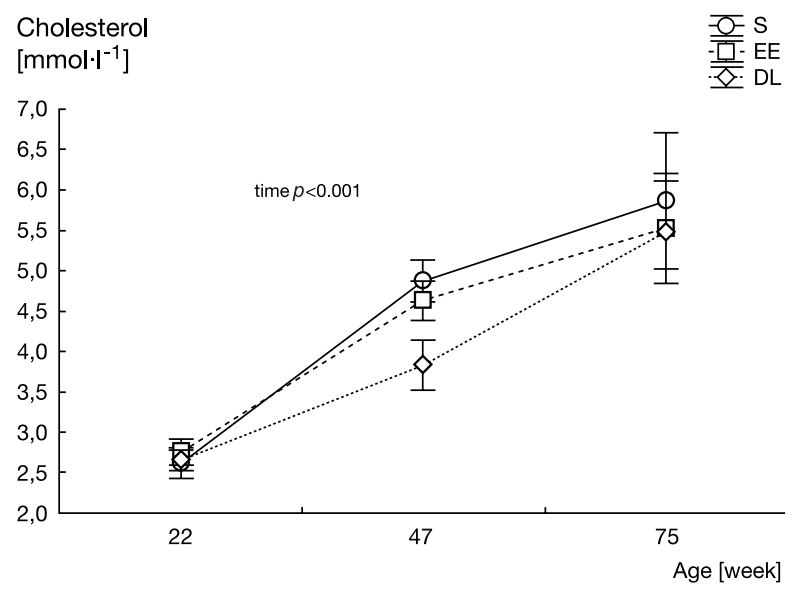

Fig. 5. Plasma cholesterol concentration in laying hens kept in conventional $(S, n=12)$, enriched $(E E, n=12)$ and deep litter $(\mathrm{DL}, \mathrm{n}=12$ ) housing system during experimental period. Data represent mean \pm S.E.M.

higher as compared with other housing systems (for factor system $\mathrm{F}(2,33)=3.568$, $p<0.05$ ), but there was no significant difference observed using two-way ANOVA with repeated measures for interaction of factors time and system $(F(4,66)=0.741$, $p=0.584$ ).

The housing system had no significant effect on the activity of ALP (Fig. 7). However, significant changes were observed during the experimental period $(\mathrm{F}(2,66)=10.627$, $p<0.001)$. The Fischer post hoc test showed a significant ALP increase $(p<0.01)$ in a conventional cage in week 47 ; the following decrease had no statistical significance. A similar trend was observed in the deep litter system. An increase and subsequent decrease was determined as significant $(p<0.01)$. In the enriched housing system an increase in week 47 was observed, which continued up to week 75 , although there was no statistical significance. 


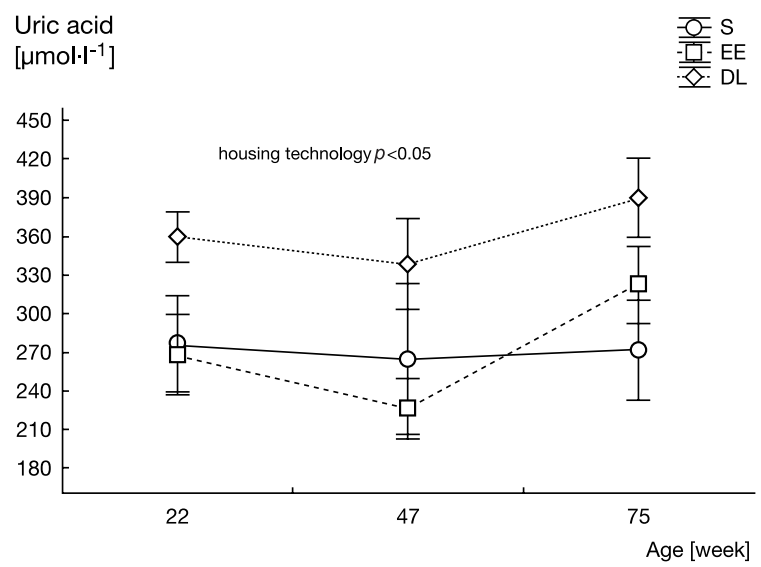

Fig. 6. Plasma uric acid concentration in laying hens kept in conventional $(S, n=12)$, enriched $(E E, n=12)$ and deep litter (DL, $n=12$ ) housing system during experimental period. Data represent mean \pm S.E.M.

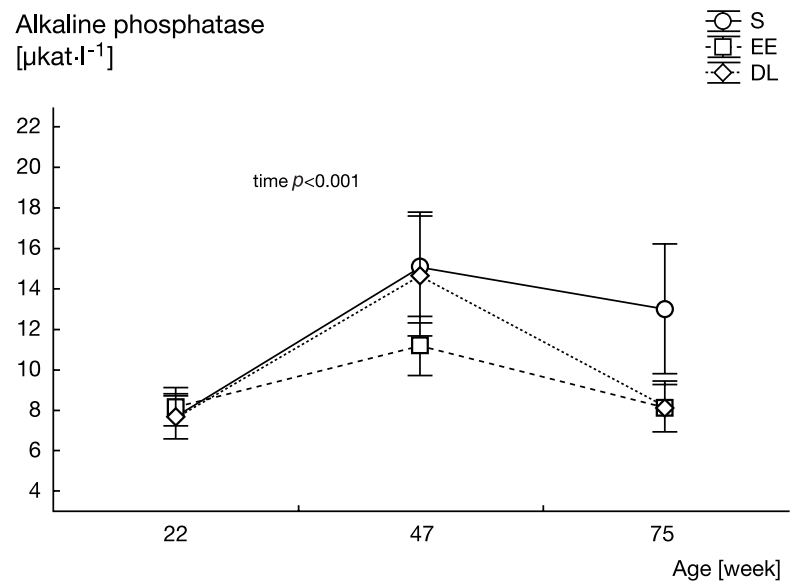

Fig. 7. Plasma alkaline phosphatase catalytic concentration in laying hens kept in conventional $(\mathrm{S}, \mathrm{n}=12)$, enriched $(E E, n=12)$ and deep litter $(D L, n=12)$ housing system during experimental period. Data represent mean \pm S.E.M.

\section{Discussion}

No distinctive differences in the concentration of total proteins in different housing systems were found and point at the fact that none of the housing systems had a negative effect and none interfered with homeostatic mechanisms keeping a steady level of blood plasma proteins. Minimal changes within the laying period are consistent with the results of Burnham et al. (2003) and a low increase in the first half of the period of observation corresponds with the results of Suchý et al. (2001). This increase may be related to the increased proteosynthesis as a prerequisite for high production of eggs during a higher intensity of egg production in this period.

The same tendency of changes of blood plasma glucose concentration during the experimental period was observed in all systems. Higher average values were observed at the beginning of the trial in week 22 of age. Glucose concentrations decreased until 
week 47 and increased at the end of the trial in week 75. An opposite trend is reported by Cerolini et al. (1990), when the glucose level in blood plasma of laying hens increased from the beginning of egg production; it did not change in the middle of the laying period and finally it significantly decreased. Nasreldin et al. (1988) report a lower level of glucose at the beginning of the laying period. Variation of the average values in a similar range as in our experiment is reported by Suchý et al. (2001, 2004). Our experiment did not prove any effect of the housing system on the concentration of glucose, which does not correspond with the results of the study by Onbasilar and Aksoy (2005) who found a decrease in serum glucose concentration at the end of the experiment compared with the level at the beginning (from weeks 34 to 56 of age). Increasing cage density, from one to five hens per cage, resulted in a significant increase of the serum glucose concentration (also found by Lagadic et al. 1990). Also Erisir and Erisir (2002) found an increase of serum glucose in female quails with higher population density. Changes in the glucose concentration in the whole period are probably associated with the intensity of egg production and with increased energy requirements. There were no significant differences found in our experiment between the average values determined in blood plasma of laying hens kept in each technology. Gunes et al. (2002) have shown, in comparison with our results, significant differences between glucose concentrations in laying hens kept in cages and in alternative technologies. The findings of Máchal and Jeřábek (2000) do not correspond in different egg production in each system, as these authors report changes of glycaemia related to the intensity of egg production.

Suchý et al. (1995) report consistently with our findings, lower levels of cholesterol in the blood plasma of younger categories of animals. In agreement with Suchý et al. (1999) we found an elevation of average values of cholesterol in the middle of the laying period. These changes of plasma cholesterol concentration are associated (Suchý et al. 1999) with the intensity of egg production, when in the case of higher intensity there is a higher level of cholesterol in the egg yolk of produced eggs and vice versa, which could be one of the causes of decreased or increased level of blood plasma cholesterol. However, these findings do not correspond with the results of Burnham et al. (2003), who determined higher concentration of cholesterol in blood plasma of laying hens at the beginning of the laying period with a following decrease during the laying period.

Increased concentration of blood plasma uric acid in the case of deep litter housing system compared with other systems could be due to a higher intake of crude protein obtained during the intake of deep litter. Sahin and Kucuk (2001) report the effect of feed withdrawal during the day and a change of the light length on the increase in uric acid concentration in the blood serum of laying hens. Also a linear increase in the dose of vitamin $E$ has an effect on the changes of uric acid concentration (Sahin et al. 2002). Considering the lower population density in the deep litter system, the study of Erisir and Erisir (2002) does not correspond with our results. These authors found that uric acid levels increased significantly with increasing stocking density in female quails.

Higher average values of ALP catalytic concentration were determined during the experimental period in conventional and enriched systems. Higher intensity of egg production was also observed in these systems during the laying period. This finding corresponds with the results of the authors Zheng et al. (2000) who found an elevated activity of alkaline phosphatase in blood plasma with simultaneous increase of the level of egg production. On the other hand, Al-Bustany et al. (1998) found no relation between the activity of ALP and production properties and do not confirm the presumption that activity of ALP is dependent on egg production. These authors observed a decreasing activity of ALP in association with increasing age of laying hens, similarly to Meluzzi et al. (1992).

In conclusion, to our knowledge, such studies comparing blood plasma metabolic profile indicators among hens kept in these three systems has not yet been performed. The achieved 
monitoring results suggest that the established values of selected indicators of internal environment, in terms of the effect of the housing system on animal health, indicate that any mentioned technology could be used without negative effects on internal conditions of laying hens. However, the results of ethological monitoring and indicators of efficiency measured in operating conditions would be conclusive for the choice of the most suitable housing system.

\section{Vliv chovatelských podmínek na biochemické ukazatele krevní plazmy nosnic}

Cílem této práce bylo porovnat vybrané biochemické ukazatele krevní plazmy nosnic ustájených ve třech rozdílných technologických systémech chovu (tradiční klecová technologie, obohacená technologie a hluboká podestýlka). V každém technologickém systému bylo sledováno 12 nosnic hybridní kombinace ISA Brown v průběhu celého snáškového cyklu od 22. do 75. týdne věku. Vzorky krve pro stanovení hladin biochemických ukazatelů byly odebírány v průběhu experimentu ve 22., 47. a 75 týdnu věku. Ukazatele metabolického profilu krevní plazmy nosnic se v průběhu snáškového cyklu pohybovaly ve všech skupinách nosnic ve fyziologickém rozmezí odpovídajícím hodnotám zdravých zvírat. V některých př́ípadech byly nalezeny statisticky průkazné rozdíly mezi jednotlivými technologickými systémy, avšak ani tyto nesignalizují jednoznačný vliv technologie ustájení na zdravotní stav sledovaných zvířat. Tyto diference jsou patrně způsobeny individuálními metabolickými rozdíly i rozdíly $\mathrm{v}$ užitkovosti jednotlivých skupin v průběhu snášky.

\section{Acknowledgement}

This study was supported by the Ministry of Agriculture, NAZV, Czech Republic, Grant No. QC1128.

\section{References}

ABRAHAMSSON P, TAUSON R 1995: Aviary systems and conventional cages for laying hens. Effects on production, egg quality, health and bird location in three hybrids. Acta Agric Scand Sect A-Anim Sci 45: 191203

AL-BUSTANY Z, AL-ATHARI AK, ABDUL-HASSAN IA 1998: Plasma alkaline phosphatase and production traits in laying hens as influenced by dietary protein, strain and age. Br Poult Sci 39: 568-571

APPLEBY MC, HUGHES BO 1991: Welfare of laying hens in cages and alternative systems: Environmental, physical and behavioural aspects. Worlds Poult Sci J 47: 109-128

APPLEBY MC, WALKER AW, NICOL CJ, LINDBERG AC, FREIRE R, HUGHES BO, ELSON HA 2002 : Development of furnished cages for laying hens. Br Poult Sci 43: 489-500

BELL DD, ADAMS CJ 1998: Environment enrichment devices for caged laying hens. J Appl Poult Res 7: 19-26

BILCIK B, KEELING LJ 1999: Changes in feather condition in relation to feather pecking and aggressive behaviour in laying hens. Br Poult Sci 40: 444-451

BURNHAM MR, PEEBLES ED, BRANTON SL, JONES MS, GERARD PD 2003: Effects of F-strain Mycoplasma gallisepticum inoculation at twelve weeks of age on the blood characteristics of commercial egg laying hens. Poult Sci 82: 1397-1402

CEROLINI S, BALDI A, CAVALCHINI LG 1990 Blood and plasma biochemical variables in laying hens of different strains and ages. Arch Geflugelkd 54: 190-194

DE BOER IJM, CORNELISSEN AMG 2002: A method using sustainability indicators to compare conventional and animal-friendly egg production systems. Poult Sci 81: 173-181

ERISIR M, ERISIR Z 2002: Changes in some biochemical blood parameters of quails (Coturnix coturnix japonica) with increasing stocking density. Turk J Vet Anim Sci 26: 491-496

GRIFFIN HD 1992: Manipulation of egg-yolk cholesterol - a physiologists view. Worlds Poult Sci J 48: 101112

GUNES N, POLAT U, PETEK M 2002: Investigation of changes in blood biochemical parameters of hens raised in alternative housing systems. Uludag Univ J Fac Vet Med 21: 39-42

KOELKEBECK KW, ODOM TW 1995: Laying hen responses to acute heat stress and carbon dioxide supplementation: II. Changes in plasma enzymes, metabolites and electrolytes. Comp Biochem Physiol APhysiol 112: 119-122

KREDATUS S, VALENT M 1993: Relationships between plane of nutrition, performance, age and biochemical parameters in the blood of laying hens. Živoč Výr 38: 153-159 
LAGADIC H, FAURE JM, MILLS AD, WILLIAMS JB 1990: Effects of blood sampling on plasma concentrations of corticosterone and glucose inlaying hens caged in groups. Br Poult Sci 31: 823-829

MÁCHAL L, JEŘÁBEK S 2000: Changes in plasma lipaemia, glycaemia and uremia caused by the negative interaction of the genotype and environment during the laying period of hens of initial lines of laying hybrids. Arch Tierz 43: 79-86

NASRELDIN RA, YOUSEF AA, MAHMOUD MF, IBRAHIM IA 1988: Thyroid-hormones, glucose, total lipids and total proteins in blood-serum before and during laying in hisex-brown chickens. J Anim Physiol Anim Nutr 59: $167-170$

ONBASILAR EE, AKSOY FT 2005: Stress parameters and immune response of layers under different cage floor and density conditions. Livest Prod Sci 95: 255-263

SAHIN K, KUCUK N, SAHIN N, GURSU MF 2002: Optimal dietary concentration of vitamin E for alleviating the effect of heat stress on performance thyroid status, ACTH and some serum metabolite and mineral concentrations in broilers. Vet Med-Czech 47: 110-116

SAHIN K, KUCUK O 2001: A simple way to reduce heat stress in laying hens as judged by egg laying, body weight gain and biochemical parameters. Acta Vet Hung 49: 421-430

SUCHÝ P, INGR I, STRAKOVÁ E 1995: Relationship between cholesterol concentrations in eggs and blood plasma of hens. Živoč Výr 40: 11-14

SUCHÝ P, STRAKOVÁ E, HRUBÝ A 1999: Variations in cholesterol concentrations in the blood plasma of hens throughout the laying period. Czech J Anim Sci 44: 109-111

SUCHÝ P, STRAKOVA E, VEČEREK V, ŠTERC P 2001: Biochemical studies of blood in hens during the laying period. Czech J Anim Sci 46: 383-387

SUCHY P, STRAKOVÁ E, JARKA B, THIEMEL J, VEČEREK V 2004: Differences between metabolic profiles of egg-type and meat-type hybrid hens. Czech J Anim Sci 49: 323-328

TAUSON R 1998: Health and production in improved cage designs. Poult Sci 77: 1820-1827

VAN HORNE PLM, BRAKE J, WILLIAMS CM 1998: Economics of controlling ammonia emission from commercial layer farms. J Appl Poult Res 7: 61-68

WALL H, TAUSON R 2002: Egg quality in furnished cages for laying hens-effects of crack reduction measures and hybrid. Poult Sci 81: 340-348

ZHENG MX, WEN WY, HUO NF, ZHOU RF 2000: Effects of compounded Chinese medicine "Jiang Dan Zeng Dan Ling" on content of cholesterol in egg. Chin J Vet Sci 20: 594-596 